\title{
Analisa Dan Desain Model Sistem Perhitungan Pajak Reklame Pada Badan Pengelola Pendapatan Daerah Kabupaten Asahan
}

\author{
Iqbal Kamil Siregar \\ STMIK Royal Kisaran \\ Jl. Prof. H. M. Yamin, S.H., No. 173 Kisaran Kab. Asahan Telp. 0623-41079 \\ Email : iqbalkamilsiregar@royal.ac.id
}

\begin{abstract}
In this era of globalization, the development of technology is no longer a new thing to talk about. Because, technology continues to develop every year. The various types of technology that are currently available are the development of pre-existing technologies. The Regional Revenue Management Agency of Asahan Regency in carrying out its activities in the advertisement tax calculation process needs to be built a system that leads to current technological progress. Analysis and design of the system model is the beginning of the development of the system followed by the existence of research methods and frameworks so that several stages are passed to get maximum results. With the design of this model, it is expected that later it can be developed to make applications both desktop and web-based, so that it can make it easier for the Asahan District Revenue Management Agency to process advertisement tax calculations and the resulting data will be more precise, fast and accurate and can also build public trust through transparent information so that people trust more and make them more aware of paying taxes on time.
\end{abstract}

Keywords : Model Design, Tax Calculation, Kab. Asahan

Abstrak-Di era globalisasi ini, perkembangan teknologi bukan lagi menjadi hal yang baru untuk dibicarakan. Sebab, teknologi terus mengalami perkembangan setiap tahunnya. Berbagai jenis teknologi yang terdapat sekarang ini merupakan pengembangan dari teknologi yang telah ada sebelumnya. Badan Pengelola Pendapatan Daerah Kabupaten Asahan dalam menjalankan kegiatannya pada proses perhitungan pajak reklame perlu dibangun suatu sistem yang mengarah kepada kemajuan teknologi saat ini. Analisa dan desain model sistem merupakan awal dari pembangunan sistem tersebut diikuti dengan adanya metode penelitian dan kerangka kerja sehingga beberapa tahapan yang dilewati mendapatkan hasil yang maksimal. Dengan adanya desain model ini diharapkan nantinya dapat dikembangkan untuk pembuatan aplikasi baik yang bersifat desktop maupun berbasis web, sehingga dapat lebih memudahkan pihak Badan Pengelola Pendapatan Daerah Kabupaten Asahan dalam melakukan pengolahan perhitungan pajak reklame serta data yang dihasilkan nantinya akan lebih tepat, cepat dan akurat dan juga bisa membangun kepercayaan masyarakat melalui informasi yang transparan sehingga masyarakat lebih percaya dan lebih menyadarkan mereka untuk mebayar pajak tepat waktu.

Kata Kunci : Desain Model, Perhitungan Pajak, Kab. Asahan

\section{PENDAHULUAN}

Di era globalisasi ini, perkembangan teknologi bukan lagi menjadi hal yang baru untuk dibicarakan. Sebab, teknologi terus mengalami perkembangan setiap tahunnya. Berbagai jenis teknologi yang terdapat sekarang ini merupakan 
pengembangan dari teknologi yang telah ada sebelumnya. Setiap inovasi akan selalu diciptakan untuk memberikan manfaat positif bagi kehidupan manusia. Memberikan banyak kemudahan, serta sebagai cara baru dalam melakukan aktifitas manusia. Khusus dalam bidang teknologi masyarakat sudah menikmati banyak manfaat yang dibawa oleh inovasi-inovasi yang telah dihasilkan dalam dekade terakhir ini. Namun demikian, walaupun pada awalnya diciptakan untuk menghasilkan manfaat positif, di sisi lain juga juga memungkinkan digunakan untuk hal negatif. Badan Pengelola Pendapatan Daerah Kabupaten Asahan dalam menjalankan kegiatannya pada proses perhitungan pajak reklame pada kantor tersebut masih menggunakan sistem semi komputer, dimana data masih diolah menggunakan semi komputer. Hal ini dirasa kurang efisien dimana proses pengolahan pajak reklame memakan waktu yang lama dan dapat membuka ruang untuk terjadinya kesalahan dalam perhitungan pajak reklame serta menimbulkan kesan seakan-akan tidak adanya transparansi biaya pada pengurusannya, selain itu memungkinkan terjadinya kecurangan dalam perhitungan biaya. Berdasarkan permasalahan diatas penulis mencoba untuk menganalisa dan men desain model sistem perhitungan pajak pada badan pengelola pendapatan Kabupaten Asahan khusunya dibagian pajak reklame.

Menurut John Burch dan Garry Grudnitski dalam buku Analisa dan Desain, Sistem Informasi Pendekatan Terstruktur adalah : "Desain sistem dapat didefinisikan sebagai penggambaran dan pembuatan sketsa atau pengaturan dari beberapa elemen yang terpisah ke dalam satu kesatuan yang utuh dan berfungsi". Dengan adanya desain model ini diharapkan nantinya dapat dikembangkan untuk pembuatan aplikasi baik yang bersifat desktop maupun berbasis web, sehingga dapat lebih memudahkan pihak Badan Pengelola Pendapatan Daerah Kabupaten Asahan dalam melakukan pengolahan perhitungan pajak reklame serta data yang dihasilkan nantinya akan lebih tepat, cepat dan akurat dan juga bisa membangun kepercayaan masyarakat melalui informasi yang transparan sehingga masyarakat lebih percaya dan lebih menyadarkan mereka untuk mebayar pajak tepat waktu .

\section{METODOLOGI PENELITIAN}

Untuk melakukan perancangan model sistem yang bagus seharusnya harus melaului tahapan-tahapan untuk mendapatkan hasil yang maksimal, gambar dibawah ini akan memperlihatkan kerngka kerja yang dilalui sehingga nantinya mendapat hasil yang maksimal

\subsection{Metode penelitian}

a. Penelitian Lapangan (Field Research)

Penelitian ini dilakukan pada Badan Pengelola Pendapatan Daerah Kabupaten Asahan dengan melakukan peninjauan dan wawancara ke pihak-pihak yang terkait.

b. Penelitian Perpustakaan (Library Research)

Study ini dilakukan untuk mencari data-data yang relevan dengan bahasan penelitian, diperoleh dari literatur-literatur yang ada.

\section{c. Penelitian Laboratorium (Laboratory Research)}


Penelitian ini adalah untuk mempraktekkan secara langsung aplikasi program komputer dalam analisa dan desain model sistem informasi pada Badan Pengelola Pendapatan Daerah Kabupaten Asahan.

\subsection{Kerangka Kerja}

Kerangka kerja penelitian ini merupakan beberapa langkah yang akan dilakukan untuk menyelesaikan permasalahan yang akan dibahas. Adapun kerangka kerja penelitian yang di gunakan seperti terlihat pada gambar dibawah ini :

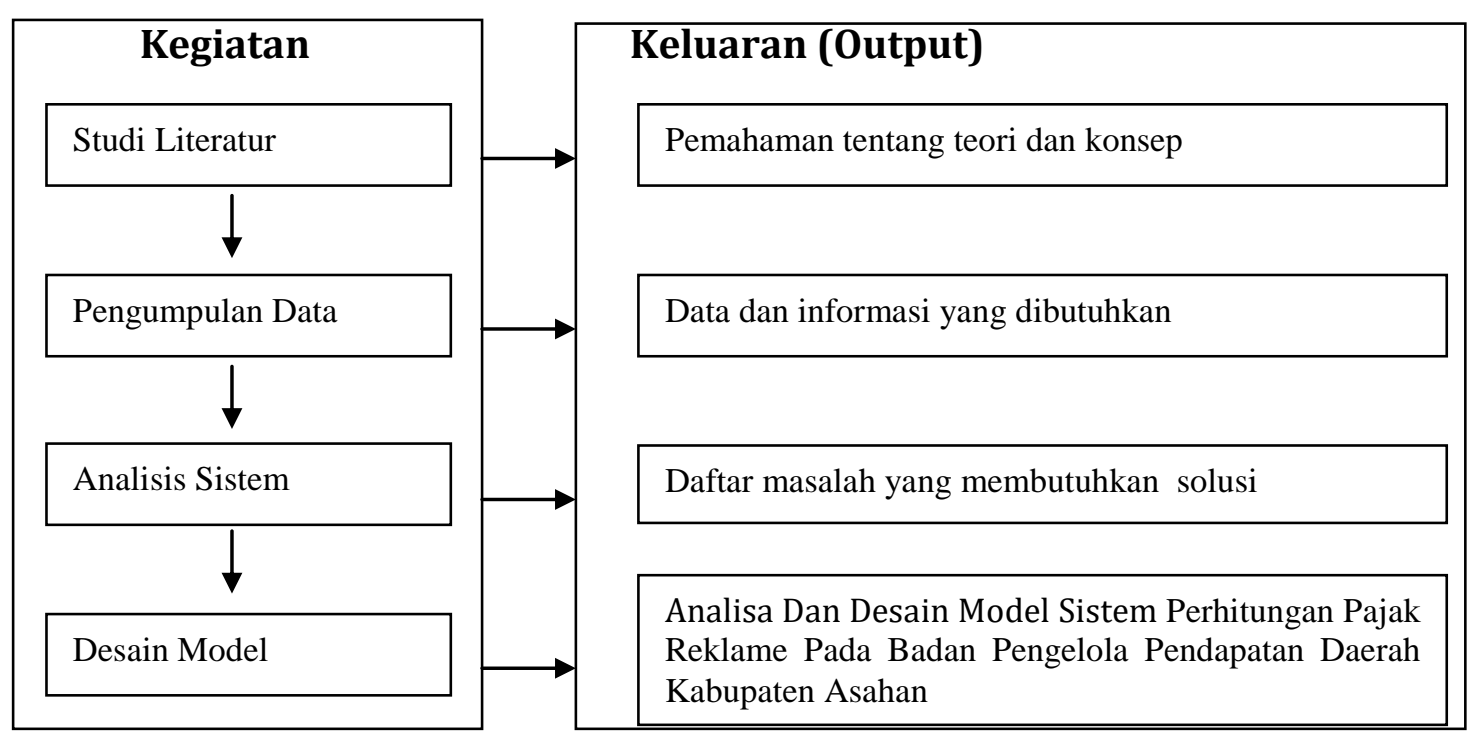

Gambar 1. Kerangka Kerja

\section{HASIL DAN PEMBAHASAN}

Tahapan analisa data merupakan tahapan yang paling penting dalam pengembangan sebuah sistem, karena pada tahap inilah nantinya dilakukan evaluasi kinerja, identifikasi terhadap masalah yang ada, rancangan sistem dan langkah-langkah yang dibutuhkan untuk perancangan yang diinginkan sampai pada analisa yang diharapakan. Tahapan Analisa Sistem ini dilakukan setelah Tahap Perencanaan sistem (system planning) dan sebelum tahap desain sistem (system design). Tahapan Analisis boleh di sebut sebagai tahapan yang kritis dan penting, mengingat tahapan analisis ini akan memberikan dampak ke perancangan sistem dalam arti lain jika ada kesalahan di tahapan ini akan menyebabkan kesalahan di tahap selanjutnya.

Dalam tahapan analisa dan desain model ini diharpkan dapat mempermudah untuk pengembangan aplikasi yang berkelanjutan, perancangan ini menggunakan alat bantu berupa UML (Unified Modeling Language) yang terdiri dari beberapa diagram, yaitu :

\subsection{Use case Diagram}


Dari penjelasan analisa sebelumnya, maka penulis mengusulkan sebuah sistem yang bisa difahami lewat Use Case diagram sebagaimana penulis jelaskan berikut ini:

Tabel 1. Actor

\begin{tabular}{|l|l|l|}
\hline No & ACTOR & PERAN \\
\hline 1 & Admin & $\begin{array}{l}\text { Sebagai administrator system yang memanajemen dan mengelola } \\
\text { sistem informasi perhitungan pajak reklame }\end{array}$ \\
\hline
\end{tabular}

Tabel 2. Use Case

\begin{tabular}{|l|l|l|}
\hline No & ACTOR & USE CASE \\
\hline 1 & Admin & 1. Mengelola Data Petugas \\
& & 2. Mengelola Data Wajib Pajak \\
& & 3. Mengelola Data SKPD (Surat Ketetapan Pajak Daerah) \\
& & 4. Mengelola Data SPTPD (Surat Pemberitahuan Terutang Pajak \\
& & Daerah) \\
& 5. Melihat Laporan \\
\hline
\end{tabular}

Berikut ini Use case Model Diagram :

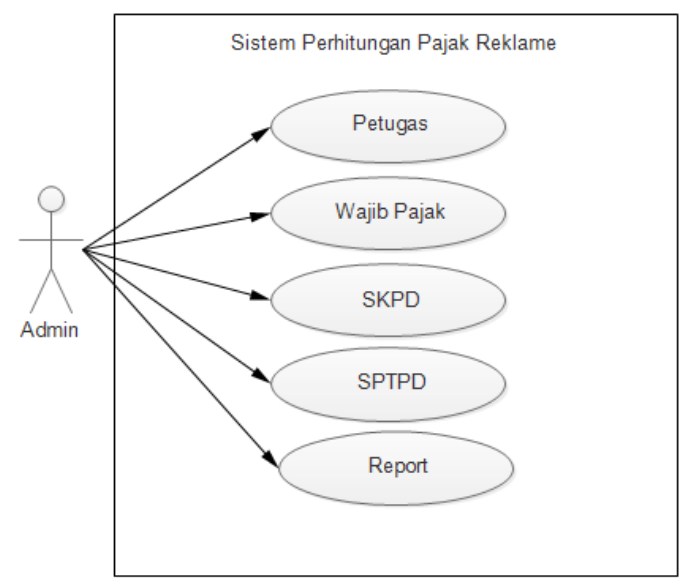

Gambar 2. Use Case Diagram

\subsection{Class Diagram}

Class diagram memberikan gambaran hubungan antara tabel-tabel yang ada dalam database. Class diagram pada studi kasus ini dapat dilihat pada gambar 3 berikut ini : 


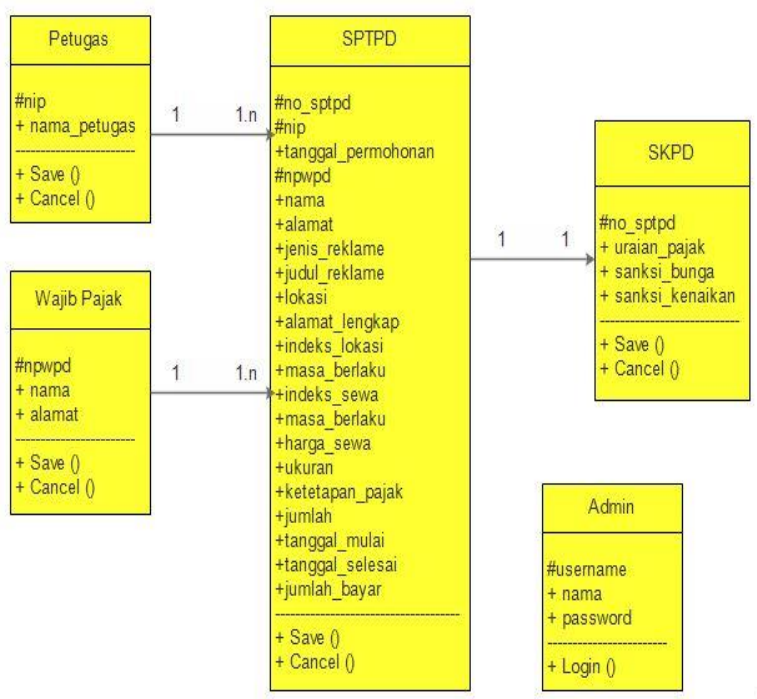

Gambar 3. Class Diagram

\subsection{Sequence Diagram}

Sequence diagram digunakan untuk menggambarkan perilaku aktor pada sebuah sistem secara detail menurut waktu. Diagram ini menunjukkan sejumlah contoh objek yang diletakkan diantara objek-objek di dalam use case. Sequence diagram yang ada pada perancangan kali ini adalah :

\subsubsection{Sequence Diagram Admin Mengelola Petugas (User)}

Diagram di bawah ini menjelaskan tahap dari admin dalam mengelola data petugas seperti pada gambar 4. Berikut ini :

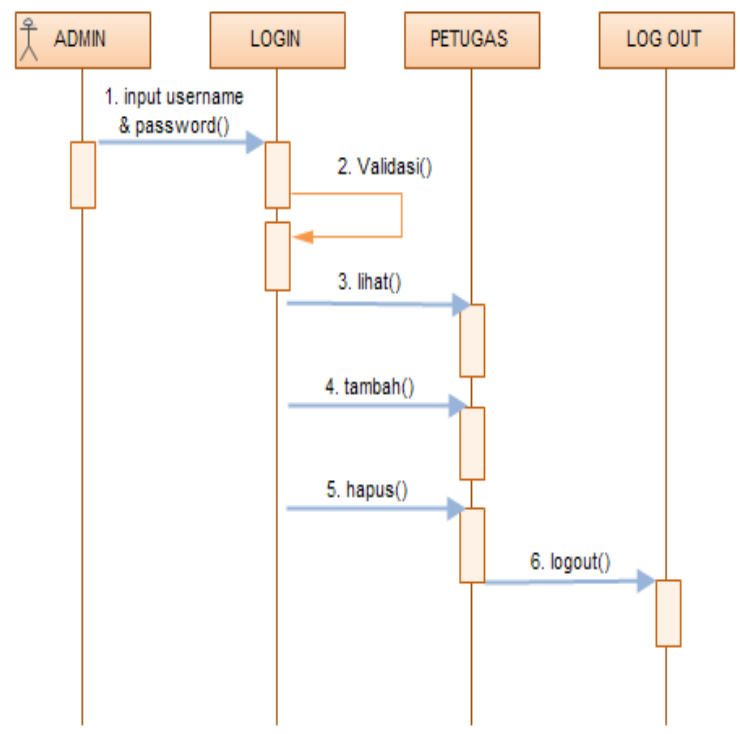

Gambar 4. Sequence Diagram Admin Mengelola Petugas (User) 


\subsubsection{Sequence Diagram Admin Mengelola Wajib Pajak}

Diagram di bawah ini menjelaskan tahap dari admin dalam mengelola data wajib pajak seperti gambar 5 berikut :

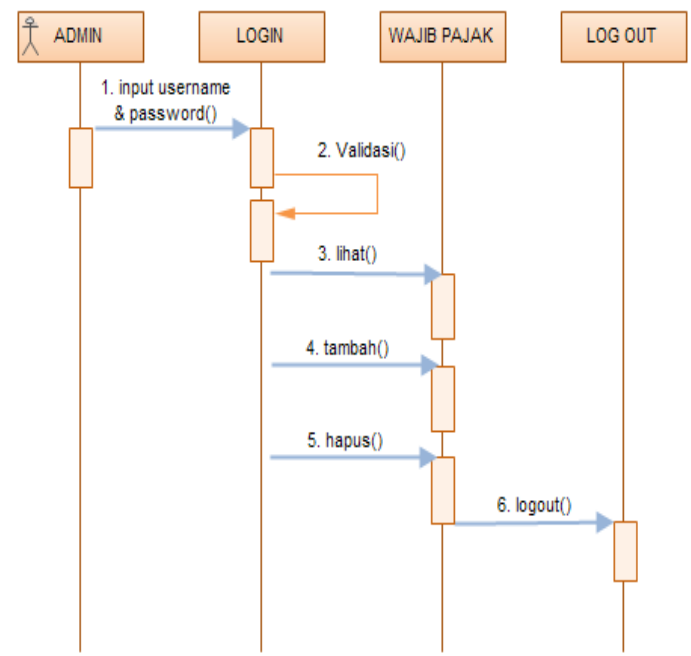

Gambar 5. Sequence Diagram Admin Mengelola Wajib Pajak

\subsubsection{Sequence Diagram Admin Mengelola SPTPD}

Diagram di bawah ini menjelaskan tahap dari admin dalam mengelola SPTPD (Surat Pemberitahuan Terutang Pajak Daerah) seperti gambar 6 berikut :

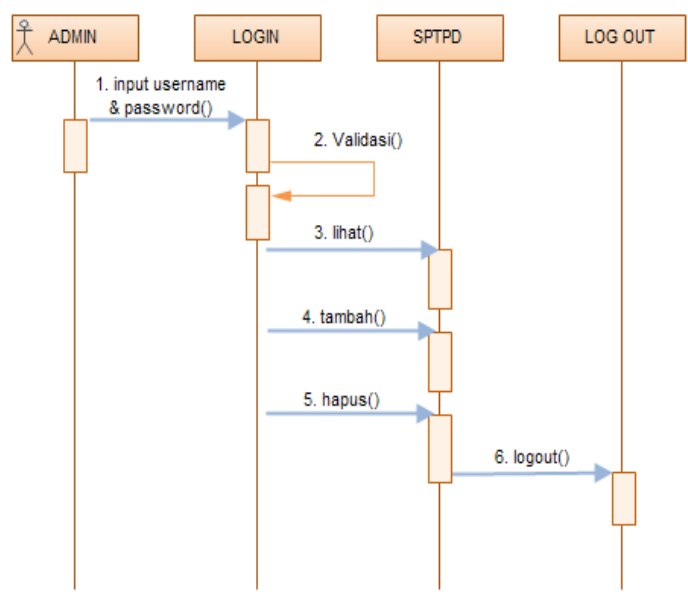

Gambar 6. Sequence Diagram Admin Mengelola SPTPD

\subsubsection{Sequence Diagram Admin Manajemen SKPD}

Diagram di bawah ini menjelaskan tahap dari admin dalam memanajemen SKPD (Surat Ketetapan Pajak Daerah) seperti gambar 6 berikut : 


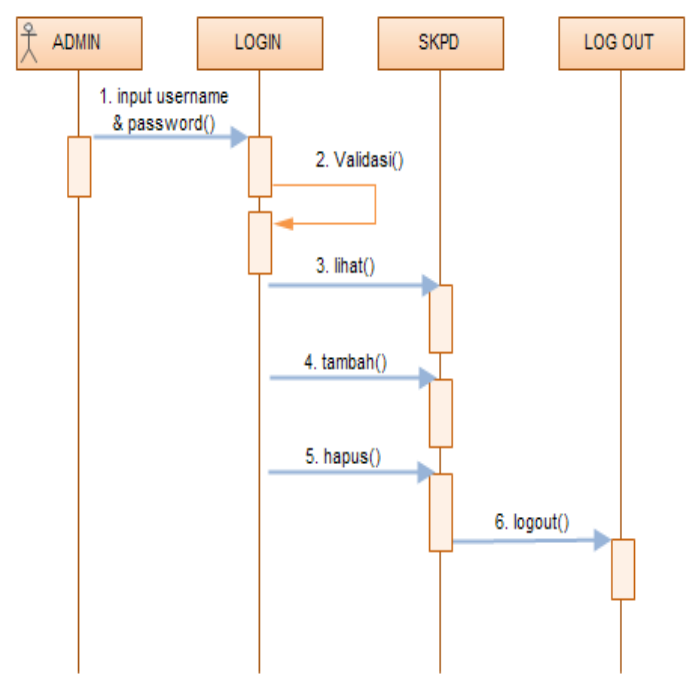

Gambar 7. Sequence Diagram Admin Mengelola SKPD

\subsection{Collaboration Diagram}

Collaboration Diagram juga dikenal sebagai Communication Diagram atau interaction Diagram, merupakan ilustrasi dari relasi dan interaksi antara objek software pada Unified Modeling Language. Berikut ini collaboration diagramnya :

\subsubsection{Collaboration Diagram Admin Mengelola Petugas (User)}

Diagram ini menjelaskan urutan langkah-langkah yang dilakukan Admin untuk mengelola data petugas (user) yang akan ditampilkan seperti gambar 7 dibawah ini :

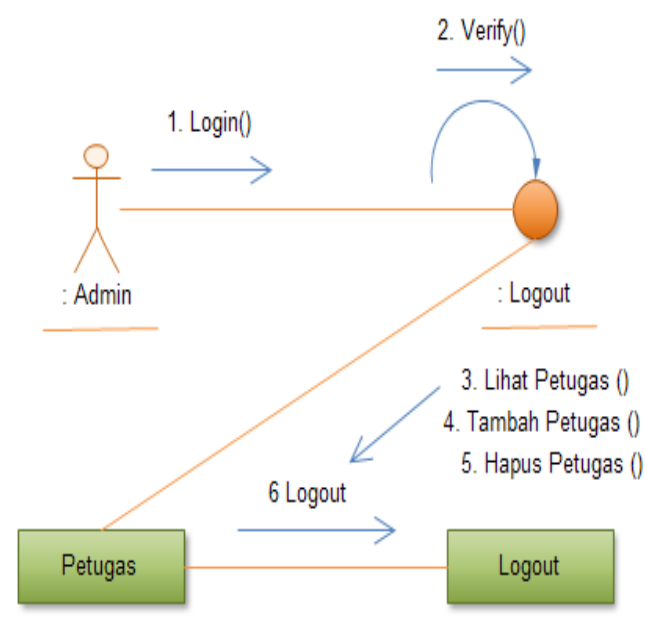

Gambar 8. Collaboration Diagram Admin Mengelola Petugas

\subsubsection{Collaboration Diagram Admin Mengelola Wajib Pajak}

Diagram ini menjelaskan urutan langkah-langkah yang dilakukan admin untuk mengelola data wajib pajak yang akan ditampilkan, seperti gambar 8 berikut ini : 


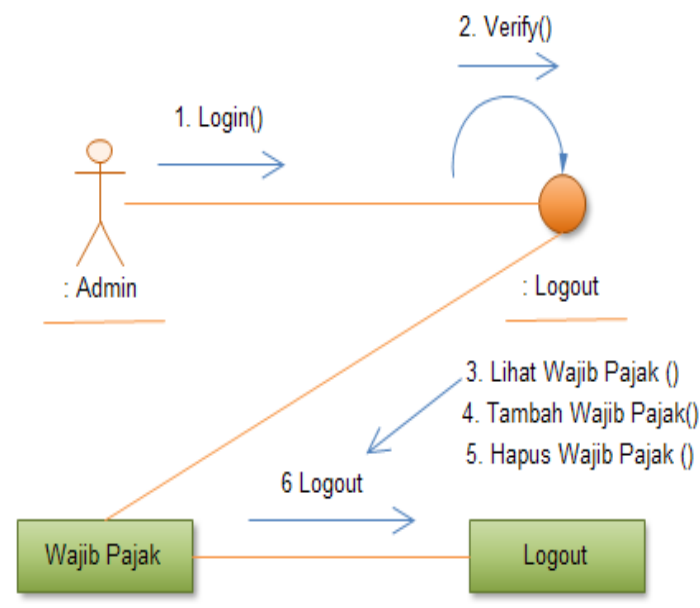

Gambar 9. Collaboration Diagram Admin Mengelola Wajib Pajak

\subsubsection{Collaboration Diagram Admin Mengelola SPTPD}

Diagram ini menjelaskan urutan langkah-langkah yang dilakukan admin untuk mengelola SPTPD (Surat Pemberitahuan Terutang Pajak Daerah) yang akan ditampilkan, seperti terlihat pada gambar 9 dibawah ini :

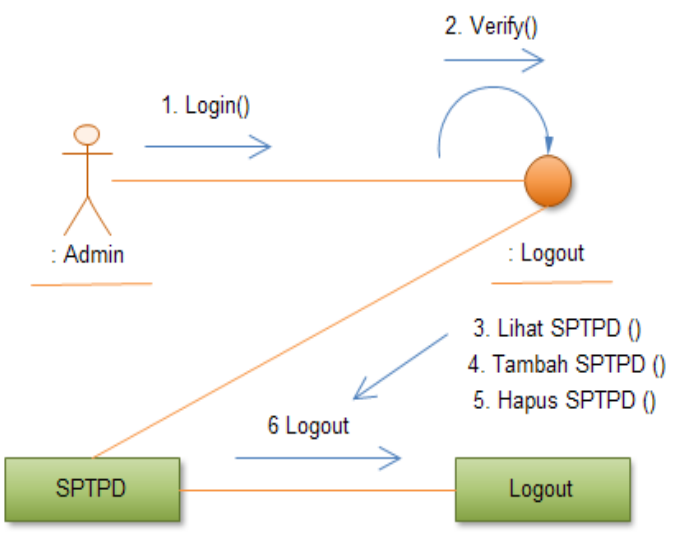

Gambar 10. Collaboration Diagram Admin Mengelola SPTPD

\subsubsection{Collaboration Diagram Admin Mengelola SKPD}

Diagram ini menjelaskan urutan langkah-langkah yang dilakukan admin untuk mengelola data SKPD (Surat Ketetapan Pajak Daerah) yang akan ditampilkan, seperti pada gambar 10 berikut ini : 


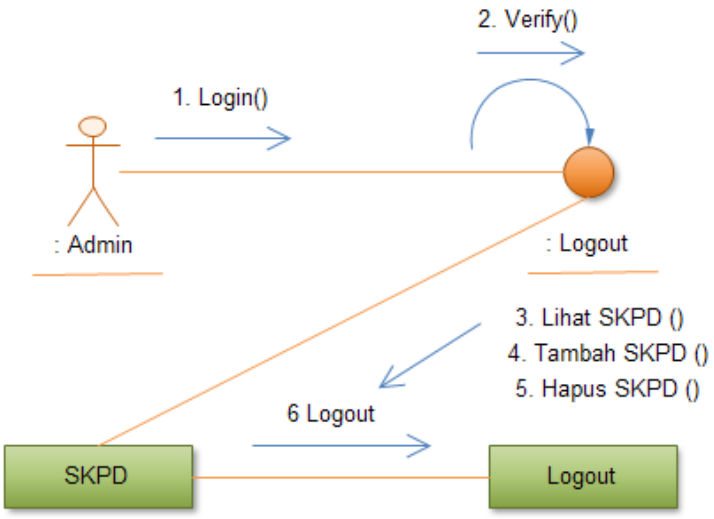

Gambar 11. Collaboration Diagram Admin Mengelola SKPD

\subsection{Activity Diagram}

Activity diagram adalah teknik untuk mendeskripsikan logika prosedural, proses bisnis dan aliran kerja yang memungkinkan setiap user untuk melakukan pilihan terhadap sistem.

\subsubsection{Activity Diagram Admin}

Activity diagram Admin menggambarkan segala aktivitas yang bisa dilakukan Admin terhadap sistem yang digambarkan seperti gambar 11 berikut:

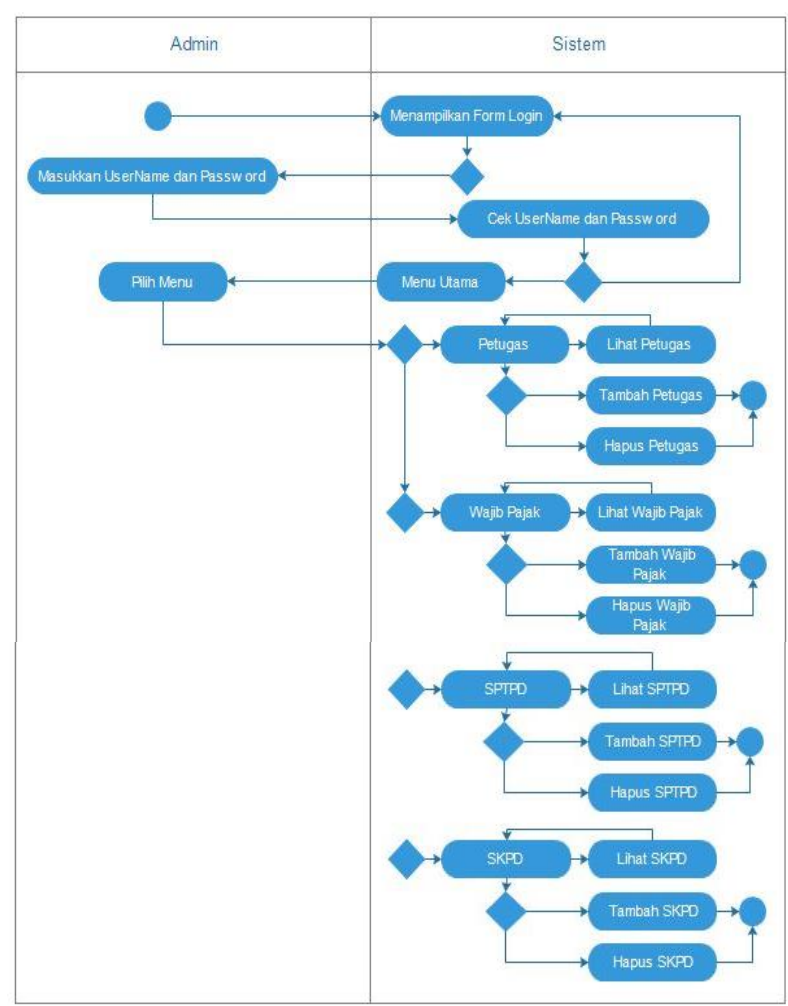

Gambar 12. Activity Diagram Admin

\section{KESIMPULAN}


Dari hasil penelitian yang telah diperoleh sejauh ini sistem informasi perhitungan pajak reklame dapat di terapkan pada kantor Badan Pengelola Pendapatan Daerah Kabipaten Asahan. Sistem tersebut dapat mengacu pada rancangan model yang telah di bangun. Pembangunan rancangan model sistem informasi perhitungan pajak reklame tersebut dilakukan setelah melakukan analisa sistem yang ada dan membandingkan dengan kebutuhan sistem yang akan datang.

Melalui sistem itu nantinya dapat dihasilkan sistem yang lebih baik sehingga pengolahan data akan lebih tepat, cepat dan akurat dan juga bisa membangun kepercayaan masyarakat melalui informasi yang transparan sehingga masyarakat lebih percaya dan lebih menyadarkan mereka untuk membayar pajak tepat waktu .

\section{DAFTAR PUSTAKA}

[1] Burch, John G. and Gary Grudnitski, "Information System Theory and Practice",5th edition,John Wiley \& Sons, Inc., Canada 1989.

[2] Siregar, I. K., \& Taufik, F. (2017). Analisa Dan Perancangan Sistem SMS Alert Untuk Pembayaran Pajak Hotel Dan Pajak Hiburan. Jurnal Manajemen Informatika dan Teknik Komputer (JURNATIK), Vol 3, No 1: 9-11.

[3] Siregar, I. K. "Analisa Dan Desain Model Sistem Informasi Dan Promosi Pada RSU Bunda Mulia Kisaran". Seminar Nasional Royal 2018.hlm 219-222

[4] Ridha, M. R. "Analisa Dan Desain Model Sistem Informasi Perpustakaan Universitas Islam Indragiri". Jurnal SISTEMASI, Volume 6, Nomor 3, September $2017: 23$ - 33

[5] Maulana, Miftah Shabur dkk. IMPLEMENTASI E-COMMERCE SEBAGAI MEDIA PENJUALAN ONLINE. Jurnal Administrasi Bisnis (JAB). Malang : Vol. 29 No. 1 Desember 2015 